\title{
SHORT-TERM SURVIVAL ESTIMATES OF THE NEW ZEALAND MUD SNAIL (POTAMOPYRGUS ANTIPODARIUM) in Polecat CREeK
}

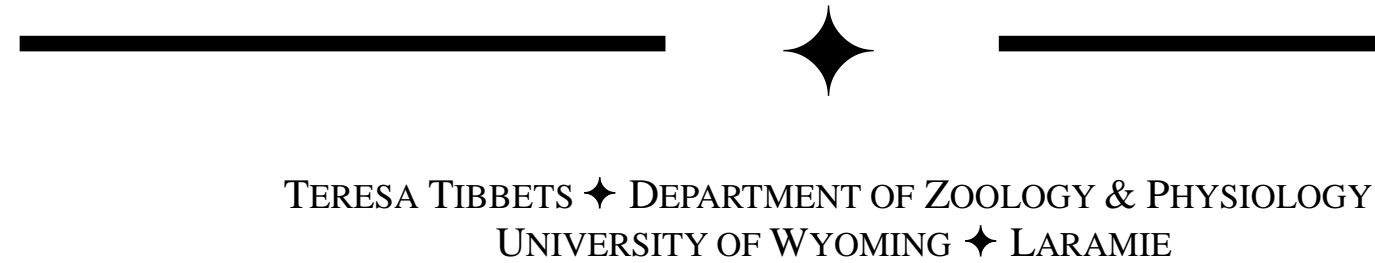

\section{$\uparrow$ AbSTRACT}

Invasive species are one of the primary threats to native biodiversity worldwide (Mack et al. 2000). Two main goals of invasion biology are to identify the mechanisms that determine which introduced species become invasive, or reach pest status, and which systems are susceptible to invasion (Heger and Trepl 2003). Therefore, it is vital to understand how invasive species sustain positive population growth rates in their introduced range. In this study, I estimated in situ survival of the invasive mud snail, Potamopyrgus antipodarium, in order to assess the population viability and life history patterns of this species in the Greater Yellowstone Area. The mean percent survival of $P$. antipodarium was $86 \%$ during the two-week study period. The field survival data is currently being used to construct a demographic population model of how $P$. antipodarum populations under different environmental conditions.

\section{$\uparrow \quad$ INTRODUCTION}

Demographic population matrix models are widely used to assess the population viability and life history patterns of a species of concern (Doak 2005, Linares et al. 2007). These demographic models are particularly valuable as an ecological tool because they allow us to study how sensitive a population is to changes in vital rates, such as fecundity or survival. Therefore, demographic population matrix models are an ideal tool to study invasive species.
The New Zealand mud snail (Potamopyrgus antipodarum), a herbivorous gastropod native to New Zealand, has spread throughout Europe, Australia, and North America (Zaranko et al. 1997), frequently reaching pest densities. Introduced populations of mud snails in Europe and North America are made up of 3 genetic clones of parthenogenic, ovoviviparous females (Dybdahl and Kane 2005) that can rapidly produce large populations in introduced freshwater habitats (Schreiber et al. 2003; Hall et al. 2006). High rates of growth and secondary production have been documented for mud snails in its introduced range (Hall et al. 2003; Dybdahl \& Kane 2005; Kerans et al. 2005), as have evidence of negative interactions between mud snails and native macroinvertebrates (Kerans et al. 2005; Riley et al. 2008) and higher trophic levels (Vinson \& Baker 2008). Another example of the potential effect of high mud snail biomass is its control of ecosystem-scale fluxes of carbon and nitrogen, as observed in Polecat Creek in the Greater Yellowstone Area (Hall et al. 2003). However, the mud snail has not reached uniformly high densities through its new range, including within Grand Teton National Park (personal observation; Kerans et al. 2005).

The long-term record of data available for $P$. antipodarum at Lower Polecat Creek in Grand Teton National Park provides a unique opportunity to study the invasion of this species over time. Specifically, the detailed population data that was collected by Dr. R. Hall et al from 2000-2002 as part of a secondary production study can be used to construct a demographic population matrix model for $P$. antipodarum. In addition, Dr. A. Krist and I have collected more recent data on the growth rate and 
fecundity of $P$. antipodarum in the laboratory (see Tibbets et al. 2009) that complements the Hall et al. 2006 dataset. However, no data is available for survival rates of $P$. antipodarum in the field. The main objective of this study was to determine the survival rates for adult $P$. antipodarium in Polecat Creek. Detailed survival data is needed for specific size classes of $P$. antipodarum in order to construct a realistic demographic population model. The construction of a demographic model for $P$. antipodarum will be a crucial tool for management of this invasive species within the GYA and the snails' invasive range worldwide.

\section{STUDY AREA}

The survival study was conducted in Polecat Creek approximately $300 \mathrm{~km}$ upstream of Huckleberry Hot Springs outlet in the John D. Rockefeller National Parkway, within the permit jurisdiction of Grand Teton National Park (UTM 12 525010E, 4883960N).

\section{$\uparrow \quad$ METHODS}

Survival of $P$. antipodarum was measured by placing a specific quantity (20) of marked mud snails into open cages in Polecat Creek from July 1 July $15^{\text {th }}, 2010$. Mud snails were marked streamside with paint markers before being counted and placed in cages in Polecat Creek (Figure 1). Cages were made of plastic sandwich-size Tupperware containers with mesh on all sides bolted to a brick. Smooth rocks covered with periphyton, but devoid of mudsnails and other invertebrates, were placed in each cage to provide an adequate food supply during the study. Dr. Amy Krist and I have successfully used this cage design at Polecat Creek in 2007 \& 2008 during our previous experiments. The lip of each cage had copper mesh securely attached to the top to serve as a barrier to snail movement in or out of the cage. This open containment allowed for estimation of mudsnail survival under more natural conditions. After 2 weeks, marked snails were collected, observed for mortality, and counted in each cage to estimate mean percent survival.

\section{$\downarrow \quad$ PRELIMINARY RESUltS}

The mean percent survival of $P$. antipodarium adults during the study was $86 \%$. Percent mortality ranged from 5 to $25 \%$. The copperlined cages successfully kept individual study snails contained within the cages during the 2 week study period. However, immigration numbers of mudsnails drifting into the cages were highly variable even though all the cages were within $\sim 1 \mathrm{~m}$ of each other in the stream. Immigration numbers ranged from 0 93 individuals. The factors controlling the spatial patterns of immigration are unknown.

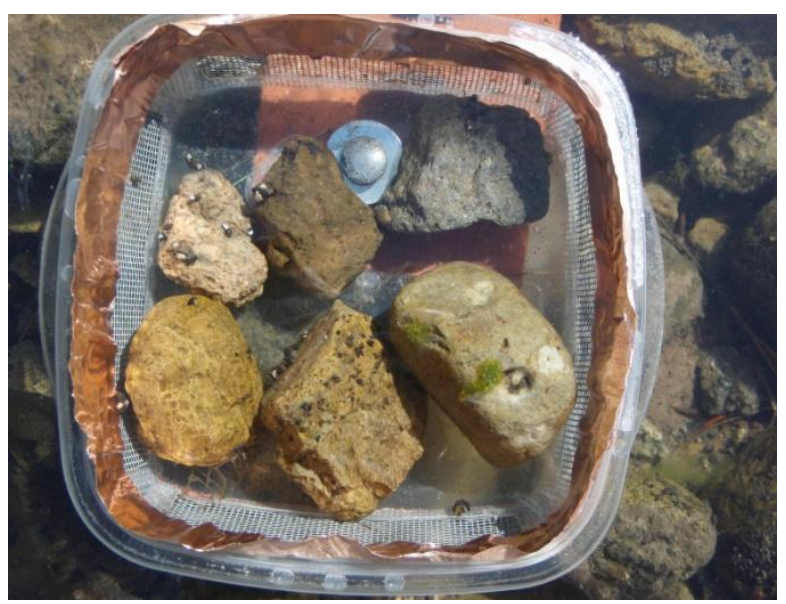

Figure 1. A close-up view of the plastic cages used in the survival study. Mudsnails were marked with white paint on their shells to assess survival of study individuals.

\section{$\downarrow$ DISCUSSION}

In situ mortality of $P$. antipodarium was similar to estimates recently published for invasive populations of this species in northern Belguim (10$30 \%$ ) (Schmitt et al. 2010). The copper-lined cages were successfully used to assess short-term survival of $P$. antipodarium in Polecat Creek. These data, in combination with additional life history data for $P$. antipodarium collected by A. Krist and R. Hall are currently being used to construct a demographic population matrix model with collaborators at the University of Wyoming. Assessment of population growth (population viability analysis) under changing environmental conditions will be estimated using this model. The construction of a demographic model for $P$. antipodarum will be a crucial tool for management of this invasive species within the GYA and the snails' invasive range worldwide.

\section{Literature Cited}

Doak DF, Morris WF, Pfister C, Kendall B, Bruna E. 2005. Correctly estimating how environmental stochasticity influences fitness and population growth. American Naturalist 166:E14-E21. 
Dybdahl MF, Kane SL. 2005. Adaptation versus phenotypic plasticity in the success of an invasive snail. Ecology 86(6):1592 - 1601.

Hall RO, Dybdahl MF, VanderLoop MC. 2006. Extremely high secondary production of introduced snails in rivers. Ecological Applications 16:1121-1131.

Hall RO Jr, Tank JL, Dybdahl MF. 2003. Exotic snails dominate nitrogen and carbon cycling in a highly productive stream. Frontiers in Ecology and the Environment. 1:407-411.

Heger T, Trepl L. 2003.Predicting biological invasions. Biological Invasions 5:313-321.

Kerans BL, Dybdahl MF, Gangloff MM, Jannot JE. 2005. Potamopyrgus antipodarum: distribution, density, and effects on native macroinvertebrate assemblages in the Greater Yellowstone Ecosystem. Journal of the North American Benthological Society. 24:123-138.

Linares C, Doak D, Coma R, Diaz D, Zabala M. 2007. Life history of a long-lived marine invertebrate: The octocoral Paramuricea clavata. Ecology. 88:918-928.

Mack RN, Simberloff D, Lonsdale WM, Evans H, Clout M, Bazzaz FA. 2000. Biotic invasions: Causes, epidemiology, global consequences, and control. Ecological Applications 10:689710 .

Riley LA, Dybdahl MF, Hall RO. 2008. Invasive species impact: asymmetric interactions between invasive and endemic freshwater snails. Journal of the North American Benthological Society 27:509-520.
Schmitt C, Vogt C, Van Ballaer B, Brix R, Suetens A, Schmitt-Jansen M, de Deckere E. 2010. In situ cage experiments with Potamopyrgus antipodarium-A novel tool for real life exposure assessment in freshwater ecosystems. Ecotoxicology and Environmental Safety 73:1574-1579.

Schreiber ESG, Quinn GP, Lake PS. 2003 Distribution of an alien aquatic snail in relation to flow variability, human activities and water quality. Freshwater Biology 48:951-961.

Tibbets TM, Krist, AK, Hall, RO, Riley LA. 2009. Phosphorous-mediated changes in life history traits of the invasive New Zealand mud snail, Potamopyrgus antipodarum. Oecologia, Online First, DOI: 10.1007/s00442-0091522-7.

Vinson M, Baker M. 2008. Poor growth of rainbow trout fed New Zealand mud snails Potamopyrgus antipodarum. North Am J Fish Management. 28:701-709.

Zaranko DT, Farara DG, Thompson FG. 1997. Another exotic mollusk in the Laurentian Great Lakes: The New Zealand native Potamopyrgus antipodarum (Gray 1843) (Gastropoda, Hydrobiidae). Can J Fish Aquat Sci 54:809-814. 